\title{
Rail Strain under Different Loads and Conditions as a Source of Information for Operation
}

\author{
M. Bruner, D. Cortis and G. Malavasi \\ Department of Civil, Building and Environmental Engineering \\ Sapienza, University of Rome, Italy
}

\begin{abstract}
The structural analysis and knowledge of the forces acting between the wheel and the rail, can give important information about the safety of the operation and the track maintenance of railways.

The complexity of the analysis comes from the variability of the wheel-rail contact point modelled by the use of multi-body simulations. The theoretical calculations, used to study this problem, are based on the finite element method.

The purpose of the work, described in this paper, is to find specific areas on the rail surfaces with stress and strain features, which allow evaluation of the influence of different loading factors. The ratio between the forces and strains could be a good index to study the rail stress. Using this ratio, it is possible to identify the effects of the different kinds of load and how the corresponding strains are affected by the boundary conditions.
\end{abstract}

Keywords: wheel-rail contact point, force measuring, shear strains, finite element model, design of experiments, rail wear.

\section{Introduction}

The rail's strain due to the passing of any trains can be used to determinate the stress state applied by the wheels. The rail in this way become a measuring device that allows, for example, the checking of the level of contact forces and can be used as a source of information for the operating safety and maintenance of the track.

The state stress is affected by a set of parameters: wheel-rail contact force depends upon many factors as the dynamic behaviour of vehicles, the functional conditions of railways infrastructure or environmental conditions. According to vehicle-tack dynamics behaviour, the forces as vertical (Q), lateral (Y) and their points of application on the railhead (position of wheel/rail contact point) are relevant to understand wheel-rail interactions. Therefore in this work the stiffness of 
fastenings, the stiffness of ballast, the different inclination of the rail $(1 / 20$ or $1 / 40)$ and the wear of the geometric profile of the railhead are considered too. In addition, the variation of the environmental conditions, as the temperature, has been taken in to account. All these factors are explored in this research.

\section{The aim of the research}

The aim of the research is the study of rail strain under different loads and functional conditions. The structural analysis and knowledge of the forces acting between the wheel and the rail, can give important information about the safety of the dynamics behaviour and the track maintenance. The studies [1], [2], [3] and specific normative [4], [5] about vehicle dynamic behaviour refer to the limiting value of derailment ratio (Y/Q), according to the cross acceptance of rolling stock or to be able to verify the track geometry quality.

The purpose of this work is to find specific areas on the rail surfaces with stress and strain features, which allow evaluation of the influence of different loading factors. For example, it is been investigated how the strain is affected by the wear of rail geometry, and if exist specific areas on rail surfaces which are influenced by these physical phenomena. The ratio between the forces and strains could be a good index to study the rail stress. Through this ratio, it is possible to identify the effects of the different kind of loads and how the corresponding strains are affected by the boundary conditions.

The paper presents the status of research, highlighting the use of the rail (accuracy, sensitivity to stress, etc.) as a source of information for the operating safety and maintenance of the track.

\section{Bibliographic background}

The study of the deformation of the rail started at the beginning of the twentieth century. Many authors [6], [7] and technical bodies have proposed a large number of researches and technical solutions.

Ahlbeck et alii [8], [9] proposed to measure the bending strain on the rail web in correspondence of the sleepers support and the shear strain between two consecutive sleepers on the rail foot to determinate the wheel-rail lateral force (Y). Harrison et alii [10] have shown more examples on the way indicated by Ahlbeck. Moreau [11] suggested to measure the shear strain on the surface of rail web to calculate the vertical force $(\mathrm{Q})$ and to measure the bending strain in the cross plane to calculate the lateral force (Y). Bocciolini et alii [12] summarized the solutions joining previous methods to reduce the uncertainties. Bruner et alii [13] calculate the lateral force on rail web starting from measurement of its strains. It is worth to note that a system for measurement of the vertical force (Q), applied to the rail by the wheel (SMCV) was developed by the University of Rome La Sapienza (Department of Civil, Building and Environmental Engineering - DICEA) [14]. This device has been installed several times by the Italian Railway Infrastructure Manager (Rete 
Ferroviaria Italiana - RFI). The same researchers are developing a new method for measurement of the lateral force (Y) applied to the rail by the wheel (SMCT). Shear strains on specific areas of the rail foot and the bending ones measured of the rail web has been tested for this method.

By the way, on commercial markets, Schenck [15] offers a solution based on the use of load cells placed at the supports of the sleepers. The system calculates the vertical and lateral force. Siemens would use this system in a plant (WegbergWildenrath) in order to the homologation of rolling stock. HBM proposes a system of measurement of the vertical forces (Q) and lateral (Y) [16], but the available documentation do not allow understanding the principle of measure.

All analysed solutions named in the bibliography, indicate the rail can be used as a measuring device for determination of the forces applied on it. But for this purpose identifying the best positions to measure the strains is needed. Of course, these positions should not be influenced by the position of wheel-rail contact forces, by the cross effects of lateral and vertical forces and by environmental conditions.

\section{$4 \quad$ Kinematic analysis}

\subsection{Choice of wheel and rail profile}

On the international railways, we can find a large number of rail profiles, which are coupled with different kinds of wheel profiles. As known the first profile of the rail wheels was cylindrical, but to improve the inscription in curve and the return of the wheelset in a centred position, respect the longitudinal axis of the track, Klingel [17] proposes the variation in the rolling radius of the wheel. Then was introduced the conical profile of the rail wheels. After a lots number of variants of rail wheel profiles were proposed. Now the design guidelines are recommended by the UIC [18], according to the different kinds of wheel-rail contact. Those guidelines are resumed in the EU technical legislations [19].

The wear of wheel and rail profiles may change the kinematic and dynamic characteristics of interaction of the train with the track. For this reason was designed and introduced a new wheel profile (S1002) that not change their principal kinematic effects with the progressive wear. This profile was also called "profile with distribute wear". Studies based on experimental tests [20] shows that the geometry of any worn wheel tends to S1002 profile. Consequently in this research was adopted the $\mathrm{S} 1002$ profile.

The profile of the rail evolves in function of the number of trains, of the speed, of the magnitude of contact forces and of the position on the track (straight line, on inner or outer rail on curves or switches). In literature, there are different predictive models for the analysis of wear of rail profile [21]. In this research, some of these models have been used in multi body software [22] to get the evolution of the rail profile. As reference wheel profile, the UIC60 with two different geometry, has been considered: the first one has no worn head profile; the second one shows a wear of $1,5 \mathrm{~mm}$ in the transverse direction, measured at $10 \mathrm{~mm}$ below the plane of rolling (Figure 1: worn profile in red line). 


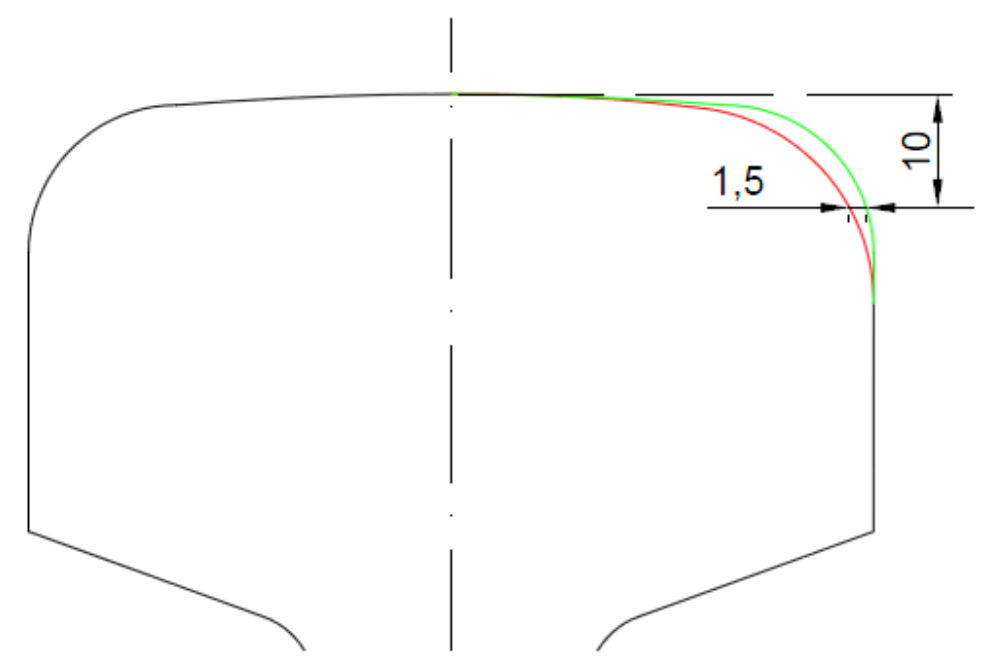

Figure 1: Worn profile

\subsection{Evaluation of wheelset bending}

In multi body simulations, the deflection of wheelset under its operating loads is considered: the first scheme has wheelset in straight track; the second one has the wheelset with a lateral displacement as the outer wheel being in contact on flange. The differences between the two load schemes can be summarized as in Figure 2. When the vertical $\left(\mathrm{Q}_{\mathrm{b} 1}, \mathrm{Q}_{\mathrm{b} 2}\right)$ and lateral $(\mathrm{H})$ loads are applied, the axle assumes a bending configuration while wheels become closed.

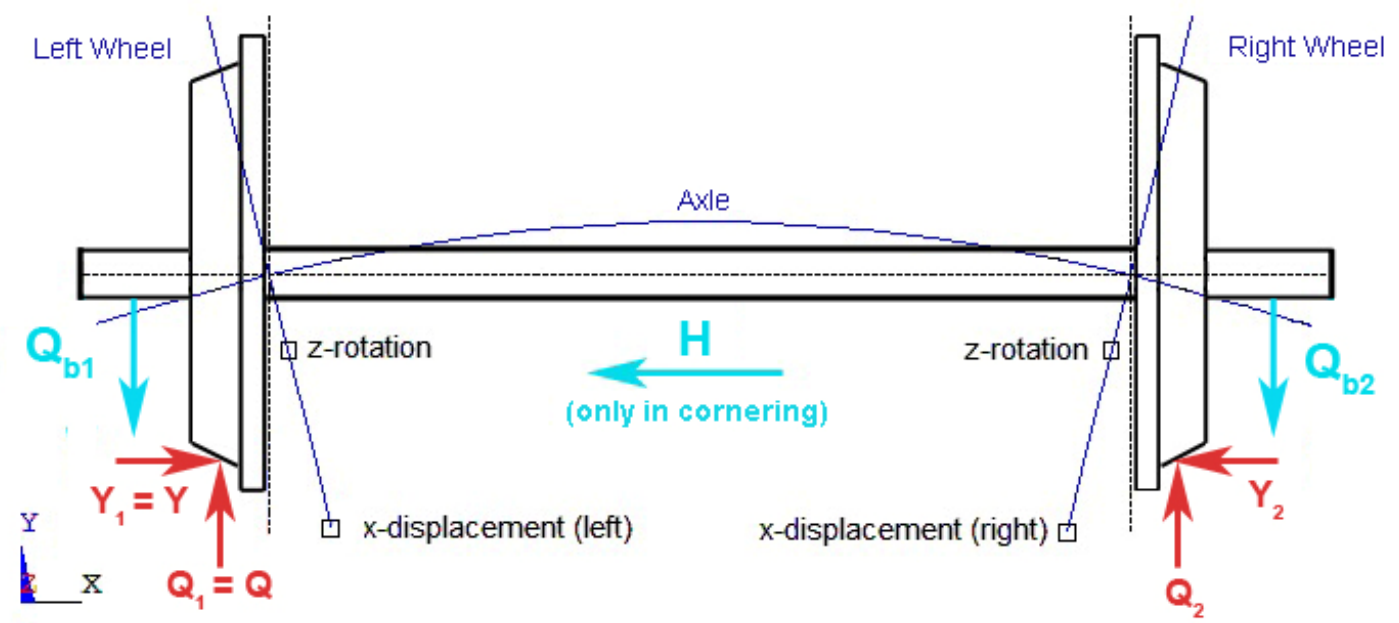

Figure 2: Wheelset load schemes

The total transversal displacements (left wheel + right wheel) have been calculated using an elementary 2D Finite Element Model. The results obtained with these simplified load schemes (Table 1) confirm the magnitude of the total transversal displacements obtained during the experimental tests conducted at the 
laboratory on a test bench. These displacements are used to modify the angle of wheel inclination into MBS simulation.

\begin{tabular}{|l|l|c|}
\hline $\begin{array}{c}\text { Loads on axle } \\
\left(\mathbf{Q}_{\mathbf{b} 1}=\mathbf{Q}_{\mathbf{b} 2}=\mathbf{Q}_{\mathbf{b}}\right)\end{array}$ & Kind of track & $\begin{array}{c}\text { Total transversal } \\
\text { displacement }\end{array}$ \\
\hline $\mathrm{Q}_{\mathrm{b}}=50 \mathrm{kN}, \mathrm{H}=0 \mathrm{kN}$ & Straight track & $0,722 \cdot 10^{-3} \mathrm{~m}$ \\
\hline $\mathrm{Q}_{\mathrm{b}}=100 \mathrm{kN}, \mathrm{H}=0 \mathrm{kN}$ & Straight track & $1,442 \cdot 10^{-3} \mathrm{~m}$ \\
\hline $\mathrm{Q}_{\mathrm{b}}=100 \mathrm{kN}, \mathrm{H}=50 \mathrm{kN}$ & Curved track & $1,978 \cdot 10^{-3} \mathrm{~m}$ \\
\hline $\mathrm{Q}_{\mathrm{b}}=100 \mathrm{kN}, \mathrm{H}=100 \mathrm{kN}$ & Curved track & $2,513 \cdot 10^{-3} \mathrm{~m}$ \\
\hline
\end{tabular}

Table 1: Total transversal displacement (left wheel + right wheel)

\subsection{The wheel-rail contact point}

The wheel profile (S1002) and the rail profile (UIC60-new and UIC60-worn) have been used to identify the contact point on the rail. The variability of the wheel-rail contact point was considered for the wheelset on straight track and on curve. The inclination of the rail has been chosen according to mostly European values 1/20 and $1 / 40$.

The parameters used in the multi body simulations are the following:

- Wheel-Rail friction factor: 0,25 (on the whole wheel-rail contact patches)

- Straight track: length $200 \mathrm{~m}$, speed $20 \mathrm{~m} / \mathrm{s}$

- Curved track: radius $300 \mathrm{~m}$, cant $90 \mathrm{~mm}$, length $300 \mathrm{~m}$, neutral speed

Some multi body results are reported in Table $2 \div 5$. The different contact points of the wheel are indicated through a local reference system in $\mathrm{x}$ and $\mathrm{y}$. The figures show the right and left wheel-rail contact areas [23] and the relative points of application of the wheel-rail contact force, vertical (Q) and lateral (Y). In the FEM simulations, the loads have been applied only on the contact points of the outer rail (left wheel-rail contact).

In the Tables $2 \div 5$, several load combinations (with a vertical force of $\mathrm{Q}=100$ $\mathrm{kN}$ and a lateral force of $\mathrm{Y}=100 \mathrm{kN}$ ) show the resulting contact patches at the related centre coordinates. About the same results are obtained choosing $\mathrm{Q}=50 \mathrm{kN}$, $\mathrm{Y}=0 \mathrm{kN}$ and $\mathrm{Q}=100 \mathrm{kN}, \mathrm{Y}=50 \mathrm{kN}$. 


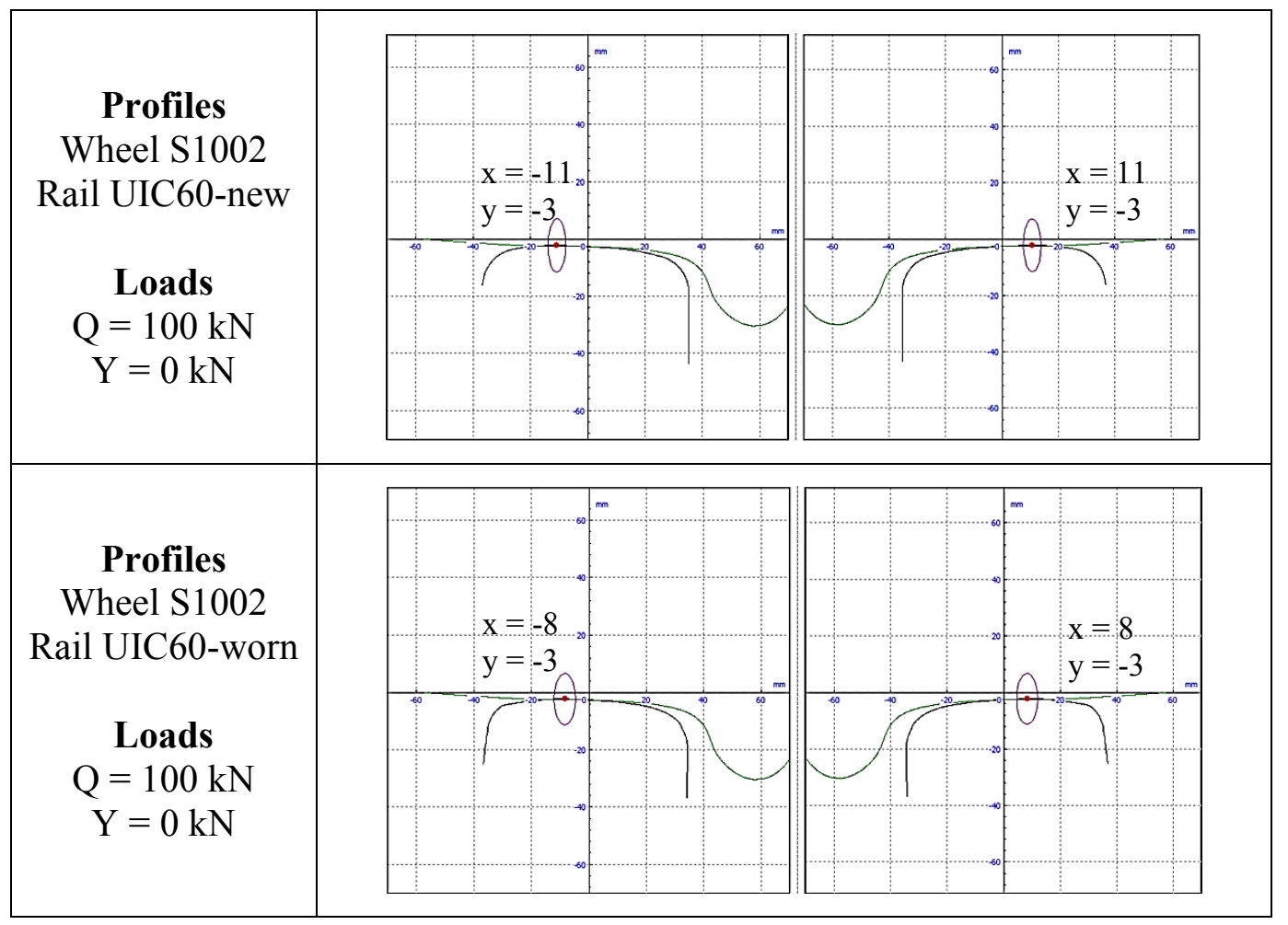

Table 2: Wheel-rail contact point. Inclination of the rail: 1/20 - Straight track

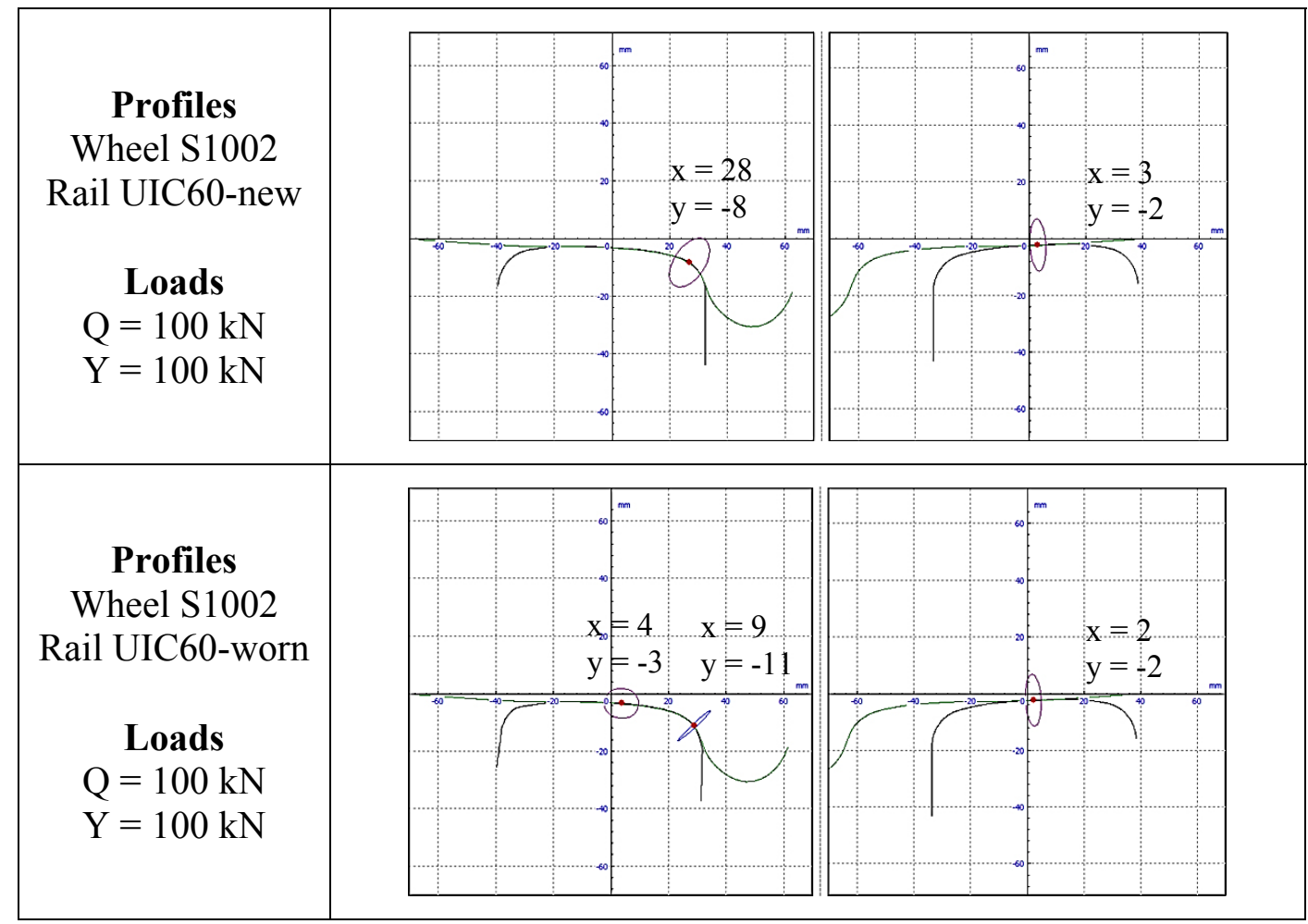

Table 3: Wheel-rail contact point. Inclination of the rail: 1/20 - Curved track 


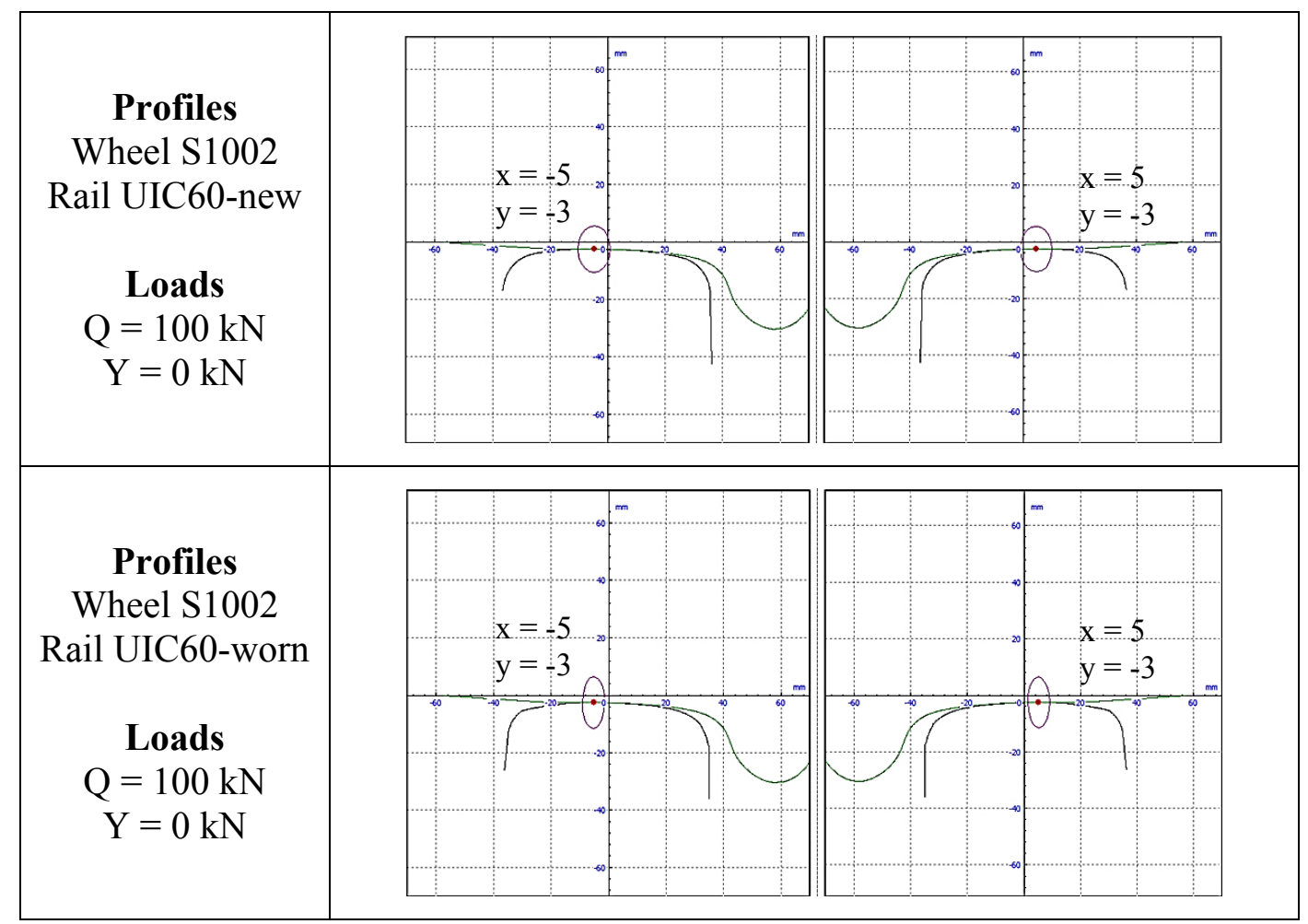

Table 4: Wheel-rail contact point. Inclination of the rail: 1/40 - Straight track

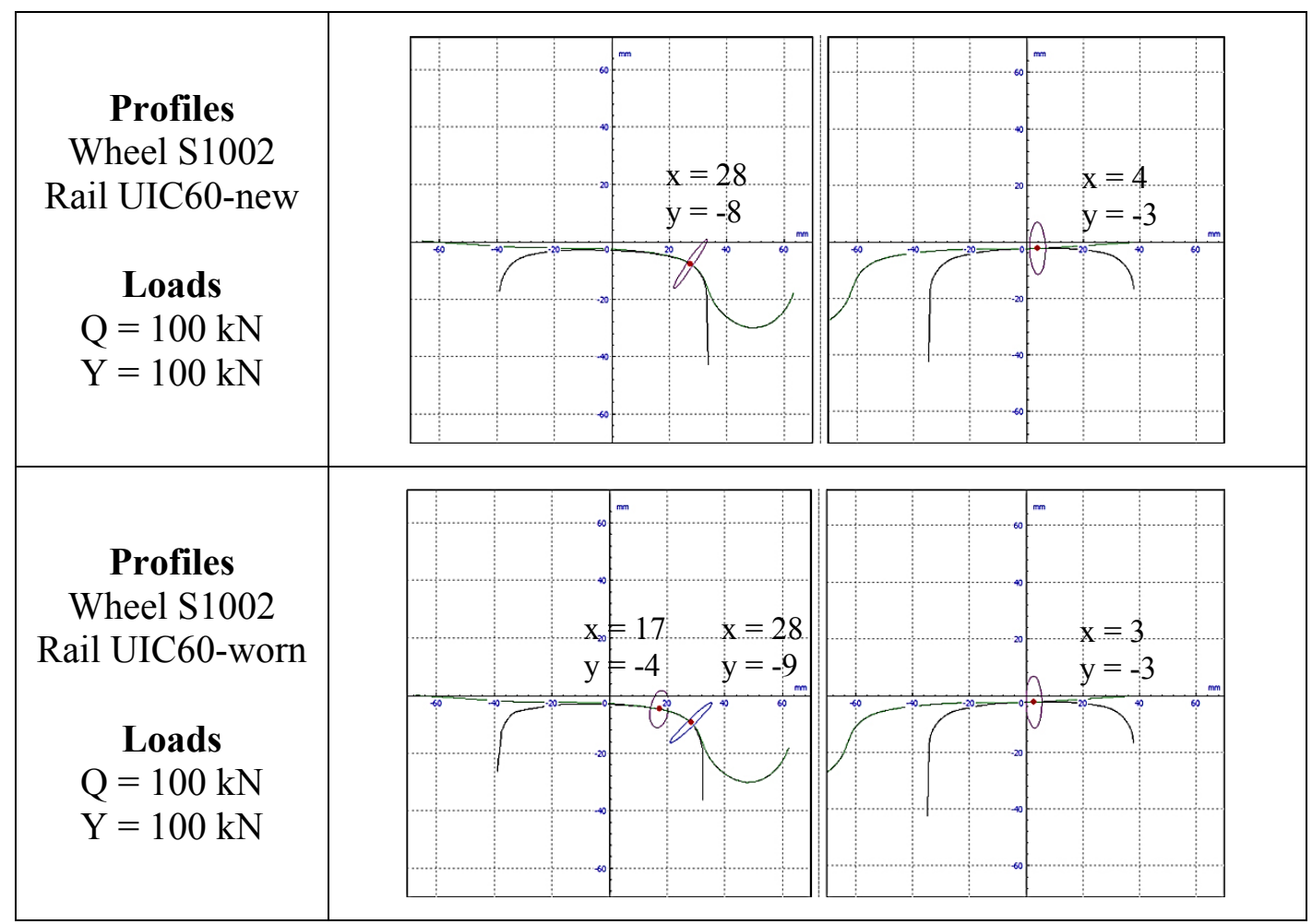

Table 5: Wheel-rail contact point. Inclination of the rail: 1/40 - Curved track 


\section{Structural analysis}

\subsection{The model}

The structural calculations are based on the Finite Element Method (FEM). A segment of the rail $(1 \mathrm{~m})$ has been modelled using a particular regular hexahedral mesh. Different combination of force, lateral (Y) and vertical (Q) are applied on railhead always on the middle span of the rail section (Figure 3 ).

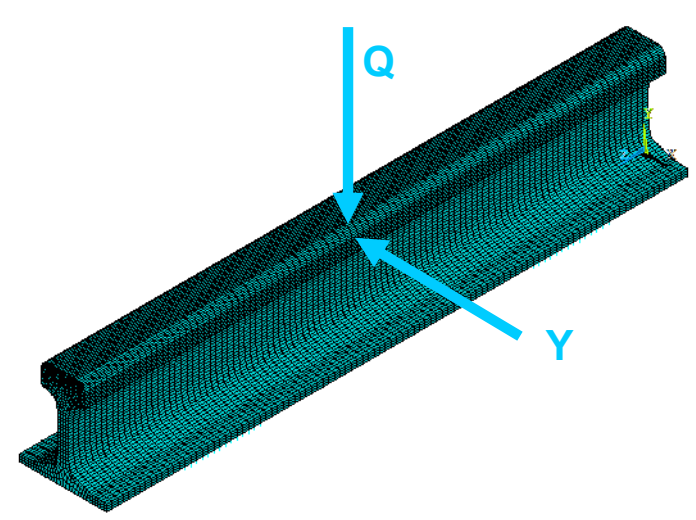

Figure 3: 3D FEM model

The surface of the rail is also covered by additional mesh using shell elements (Figure 4). These shell elements produced the same strain as electric strain gages applied on surface of the real rail. The rail is connected to the theoretical ground by spring elements representing the joints (elastic indirect fastenings) between rail and sleeper (Figure 4). A variable thermal gradient is considered. Wear of rail geometry is simulated changing the railhead profile. Complexity of analysis comes from the variability of the wheel-rail contact points.

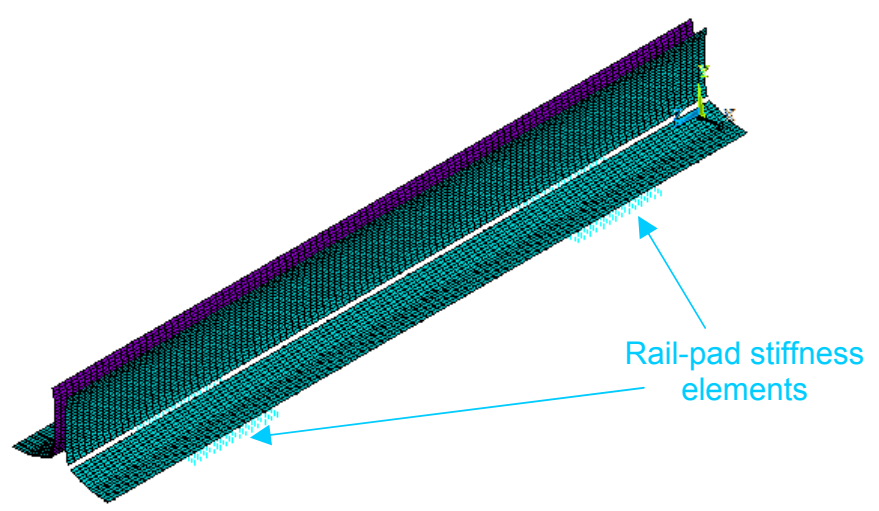

Figure 4: 2D Shell and spring elements

The longitudinal size of the hexahedral elements at rail foot and at rail web is $10 \mathrm{~mm}$ and the transversal size is $5 \mathrm{~mm}$. Transversal size meshing of model is $1 \mathrm{~mm}$ wide. The spring elements have a vertical length of $5 \mathrm{~mm}$. 


\subsection{Validation by experimental tests}

The model was validated through experimental tests developed in the laboratory. The test were conducted on a segment of the rail. For each test the sum of strains $(\Sigma \varepsilon)$ by four strain gauges located on the rail foot in two sections, symmetrically disposed respect the middle of the rail, were measured. The distance of strain gauges from the middle of the rail is $\pm 60 \mathrm{~mm}$, while the distance from the external edge of the rail foot is $20 \mathrm{~mm}$. The strain gauges combination is based on SMCT method [24]. The comparative results are report in Table 6 . The maximum error between the experimental result and theoretical result is $12 \%$. However the model has been significant to able to simulate the real rail stress behaviour (thermal gradient, loads combinations). The average error (about 7\%) could be reduced by refining model or introducing new parameter approximating operating conditions.

\begin{tabular}{|c|c|c|c|c|}
\hline \multicolumn{2}{|c|}{ Loads } & Experimental results & Theoretical results & Error \\
\hline $\mathbf{Q}$ & $\mathbf{Y}$ & $\mathbf{a}=\mathbf{\Sigma}_{\exp }$ & $\mathbf{b}=\mathbf{\Sigma}_{\boldsymbol{\varepsilon}_{\mathrm{fem}}}$ & $\mid(\mathbf{a}-\mathbf{b}) / \mathbf{a}$ \\
\hline $20 \mathrm{kN}$ & $10 \mathrm{kN}$ & $45,3 \mu \varepsilon$ & $41,8 \mu \varepsilon$ & $7,7 \%$ \\
\hline $30 \mathrm{kN}$ & $10 \mathrm{kN}$ & $41,3 \mu \varepsilon$ & $39,1 \mu \varepsilon$ & $5,3 \%$ \\
\hline $30 \mathrm{kN}$ & $20 \mathrm{kN}$ & $96,7 \mu \varepsilon$ & $85,2 \mu \varepsilon$ & $11,9 \%$ \\
\hline $40 \mathrm{kN}$ & $10 \mathrm{kN}$ & $36,7 \mu \varepsilon$ & $36,4 \mu \varepsilon$ & $0,8 \%$ \\
\hline $40 \mathrm{kN}$ & $20 \mathrm{kN}$ & $92,0 \mu \varepsilon$ & $83,6 \mu \varepsilon$ & $9,1 \%$ \\
\hline $40 \mathrm{kN}$ & $40 \mathrm{kN}$ & $192,0 \mu \varepsilon$ & $176,6 \mu \varepsilon$ & $9,0 \%$ \\
\hline
\end{tabular}

Table 6: Experimental results VS Theoretical results

\subsection{Test runs}

The parameters could affect the strain state of the rail are:

1) loads: combination of vertical $(\mathrm{Q})$ and lateral $(Y)$ force

2) thermal gradient $(\Delta T)$

3) inclination of the rail $(\alpha)$

4) status of the rail profile (new or worn)

5) stiffness of fastenings and ballast (R)

For each parameters, two values were set. The track conditions, straight line and curved track, are considered as individually experiment condition. In this case, the full factorial experiment design required 32 simulation runs for each track conditions $\left(2^{5}=32\right.$ runs). The total combinations for the numerical tests are $64(32 \mathrm{x}$ $2=64$ runs).

To study the effect of different parameters /factors, the Design of Experiments method (DOE) has been applied. DOE is an extremely practical and cost-effective way to study the effects of different factors and their interactions on a response function. To reduce the number of simulations a fractional factorial designs method has been taken in to account. Fractional factorial designs are experimental designs consisting of a carefully chosen subset of the experimental runs of a full factorial design. This method reduce costs and time needed for the numerical experiments. 
An important property of a fractional design is its resolution or ability to separate main effects and low-order interactions from one another. In this case, we used a half fraction of a full factorial design $\left(2^{5-1}=16\right.$ runs) with $\mathrm{V}$ resolution in which no main effect or two-factor interaction is aliased with any other main effect or twofactor interaction. The number of simulations has been cut by 50\% (16 x $2=32$ runs) without losing precision and experimental relevance. In DOE method, all parameters are suppose independent. The combinations of numerical simulations are report in Tables 7 and 8.

\begin{tabular}{|c|c|c|c|c|c|}
\hline $\mathbf{n}$ & Loads & $\Delta \mathrm{T}$ & $\alpha$ & Rail profile & $\mathbf{R}$ \\
\hline 1 & Q 50kN - Y 0kN & $0^{\circ} \mathrm{C}$ & $1 / 40$ & new & $1 \cdot 10^{30} \mathrm{~N} / \mathrm{m}$ \\
\hline 2 & Q 50kN - Y 0kN & $0^{\circ} \mathrm{C}$ & $1 / 40$ & worn & $75 \cdot 10^{6} \mathrm{~N} / \mathrm{m}$ \\
\hline 3 & Q 50kN - Y 0kN & $0^{\circ} \mathrm{C}$ & $1 / 20$ & new & $75 \cdot 10^{6} \mathrm{~N} / \mathrm{m}$ \\
\hline 4 & Q 50kN - Y 0kN & $0{ }^{\circ} \mathrm{C}$ & $1 / 20$ & worn & $1 \cdot 10^{30} \mathrm{~N} / \mathrm{m}$ \\
\hline 5 & Q 50kN - Y 0kN & $50^{\circ} \mathrm{C}$ & $1 / 40$ & new & $75 \cdot 10^{6} \mathrm{~N} / \mathrm{m}$ \\
\hline 6 & Q 50kN - Y 0kN & $50^{\circ} \mathrm{C}$ & $1 / 40$ & worn & $1 \cdot 10^{30} \mathrm{~N} / \mathrm{m}$ \\
\hline 7 & Q 50kN - Y 0kN & $50^{\circ} \mathrm{C}$ & $1 / 20$ & new & $1 \cdot 10^{30} \mathrm{~N} / \mathrm{m}$ \\
\hline 8 & Q 50kN - Y 0kN & $50^{\circ} \mathrm{C}$ & $1 / 20$ & worn & $75 \cdot 10^{6} \mathrm{~N} / \mathrm{m}$ \\
\hline 9 & Q $100 \mathrm{kN}-\mathrm{Y} 0 \mathrm{kN}$ & $0^{\circ} \mathrm{C}$ & $1 / 40$ & new & $75 \cdot 10^{6} \mathrm{~N} / \mathrm{m}$ \\
\hline 10 & Q $100 \mathrm{kN}-\mathrm{Y} 0 \mathrm{kN}$ & $0{ }^{\circ} \mathrm{C}$ & $1 / 40$ & worn & $1 \cdot 10^{30} \mathrm{~N} / \mathrm{m}$ \\
\hline 11 & Q $100 \mathrm{kN}-\mathrm{Y} 0 \mathrm{kN}$ & $0^{\circ} \mathrm{C}$ & $1 / 20$ & new & $1 \cdot 10^{30} \mathrm{~N} / \mathrm{m}$ \\
\hline 12 & Q $100 \mathrm{kN}-\mathrm{Y} 0 \mathrm{kN}$ & $0^{\circ} \mathrm{C}$ & $1 / 20$ & worn & $75 \cdot 10^{6} \mathrm{~N} / \mathrm{m}$ \\
\hline 13 & Q $100 \mathrm{kN}-\mathrm{Y} 0 \mathrm{kN}$ & $50{ }^{\circ} \mathrm{C}$ & $1 / 40$ & new & $1 \cdot 10^{30} \mathrm{~N} / \mathrm{m}$ \\
\hline 14 & Q $100 \mathrm{kN}-\mathrm{Y} 0 \mathrm{kN}$ & $50^{\circ} \mathrm{C}$ & $1 / 40$ & worn & $75 \cdot 10^{6} \mathrm{~N} / \mathrm{m}$ \\
\hline 15 & Q $100 \mathrm{kN}-\mathrm{Y} 0 \mathrm{kN}$ & $50^{\circ} \mathrm{C}$ & $1 / 20$ & new & $75 \cdot 10^{6} \mathrm{~N} / \mathrm{m}$ \\
\hline 16 & Q $100 \mathrm{kN}-\mathrm{Y} 0 \mathrm{kN}$ & $50^{\circ} \mathrm{C}$ & $1 / 20$ & worn & $1 \cdot 10^{30} \mathrm{~N} / \mathrm{m}$ \\
\hline
\end{tabular}

Table 7: Simulation test runs (DOE half fraction design) - Straight track

\begin{tabular}{|c|c|c|c|c|c|}
\hline $\mathbf{n}$ & Loads & $\Delta T$ & $\alpha$ & Rail profile & $\mathbf{R}$ \\
\hline 1 & Q 100kN - Y 50kN & $0^{\circ} \mathrm{C}$ & $1 / 40$ & new & $1 \cdot 10^{30} \mathrm{~N} / \mathrm{m}$ \\
\hline 2 & Q 100kN - Y 50kN & $0^{\circ} \mathrm{C}$ & $1 / 40$ & worn & $75 \cdot 10^{6} \mathrm{~N} / \mathrm{m}$ \\
\hline 3 & Q $100 \mathrm{kN}-\mathrm{Y} 50 \mathrm{kN}$ & $0^{\circ} \mathrm{C}$ & $1 / 20$ & new & $75 \cdot 10^{6} \mathrm{~N} / \mathrm{m}$ \\
\hline 4 & Q $100 \mathrm{kN}-\mathrm{Y} 50 \mathrm{kN}$ & $0^{\circ} \mathrm{C}$ & $1 / 20$ & worn & $1 \cdot 10^{30} \mathrm{~N} / \mathrm{m}$ \\
\hline 5 & Q 100kN - Y 50kN & $50^{\circ} \mathrm{C}$ & $1 / 40$ & new & $75 \cdot 10^{6} \mathrm{~N} / \mathrm{m}$ \\
\hline 6 & Q $100 \mathrm{kN}-\mathrm{Y} 50 \mathrm{kN}$ & $50^{\circ} \mathrm{C}$ & $1 / 40$ & worn & $1 \cdot 10^{30} \mathrm{~N} / \mathrm{m}$ \\
\hline 7 & Q $100 \mathrm{kN}-$ Y $50 \mathrm{kN}$ & $50^{\circ} \mathrm{C}$ & $1 / 20$ & new & $1 \cdot 10^{30} \mathrm{~N} / \mathrm{m}$ \\
\hline 8 & Q $100 \mathrm{kN}-\mathrm{Y} 50 \mathrm{kN}$ & $50^{\circ} \mathrm{C}$ & $1 / 20$ & worn & $75 \cdot 10^{6} \mathrm{~N} / \mathrm{m}$ \\
\hline 9 & Q $100 \mathrm{kN}-\mathrm{Y} 100 \mathrm{kN}$ & $0^{\circ} \mathrm{C}$ & $1 / 40$ & new & $75 \cdot 10^{6} \mathrm{~N} / \mathrm{m}$ \\
\hline 10 & Q $100 \mathrm{kN}-\mathrm{Y} 100 \mathrm{kN}$ & $0^{\circ} \mathrm{C}$ & $1 / 40$ & worn & $1 \cdot 10^{30} \mathrm{~N} / \mathrm{m}$ \\
\hline 11 & Q $100 \mathrm{kN}-\mathrm{Y} 100 \mathrm{kN}$ & $0^{\circ} \mathrm{C}$ & $1 / 20$ & new & $1 \cdot 10^{30} \mathrm{~N} / \mathrm{m}$ \\
\hline 12 & Q 100kN-Y 100kN & $0^{\circ} \mathrm{C}$ & $1 / 20$ & worn & $75 \cdot 10^{6} \mathrm{~N} / \mathrm{m}$ \\
\hline 13 & Q $100 \mathrm{kN}-\mathrm{Y} 100 \mathrm{kN}$ & $50^{\circ} \mathrm{C}$ & $1 / 40$ & new & $1 \cdot 10^{30} \mathrm{~N} / \mathrm{m}$ \\
\hline 14 & Q $100 \mathrm{kN}-\mathrm{Y} 100 \mathrm{kN}$ & $50^{\circ} \mathrm{C}$ & $1 / 40$ & worn & $75 \cdot 10^{6} \mathrm{~N} / \mathrm{m}$ \\
\hline 15 & Q $100 \mathrm{kN}-\mathrm{Y} 100 \mathrm{kN}$ & $50^{\circ} \mathrm{C}$ & $1 / 20$ & new & $75 \cdot 10^{6} \mathrm{~N} / \mathrm{m}$ \\
\hline 16 & Q $100 \mathrm{kN}-\mathrm{Y} 100 \mathrm{kN}$ & $50^{\circ} \mathrm{C}$ & $1 / 20$ & worn & $1 \cdot 10^{30} \mathrm{~N} / \mathrm{m}$ \\
\hline
\end{tabular}

Table 8: Simulation test runs (DOE half fraction design) - Curved track 


\section{Results}

\subsection{Shear strain on the rail web}

The Figure 5 and 6 show the shear strain on the rail web (inner surface) under different loads conditions for straight track. There is the constant value of the shear strain in the middle on the rail. The level of strain in both figure shows the same value and the same trend along the longitudinal axis. This result is in according to the shear diagram due to a concentrated force on a traditional beam.

The system for measurement of the vertical force has been installed by the Italian Railway Infrastructure Manager (Rete Ferroviaria Italiana - RFI), is based on this shear state on the rail web. This confirms the validity of our analysis.

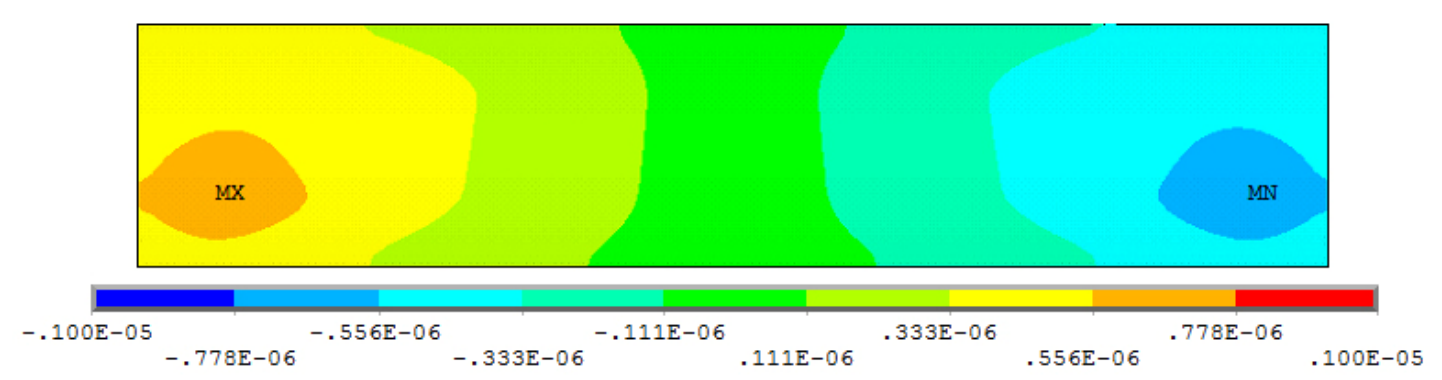

Figure 5: Strain on the rail web - inner surface (Straight track, Q50-Y0 kN, T $+0^{\circ} \mathrm{C}$, $\alpha=1 / 20, \mathrm{R}=75 \mathrm{MN} / \mathrm{m}$, New rail profile)

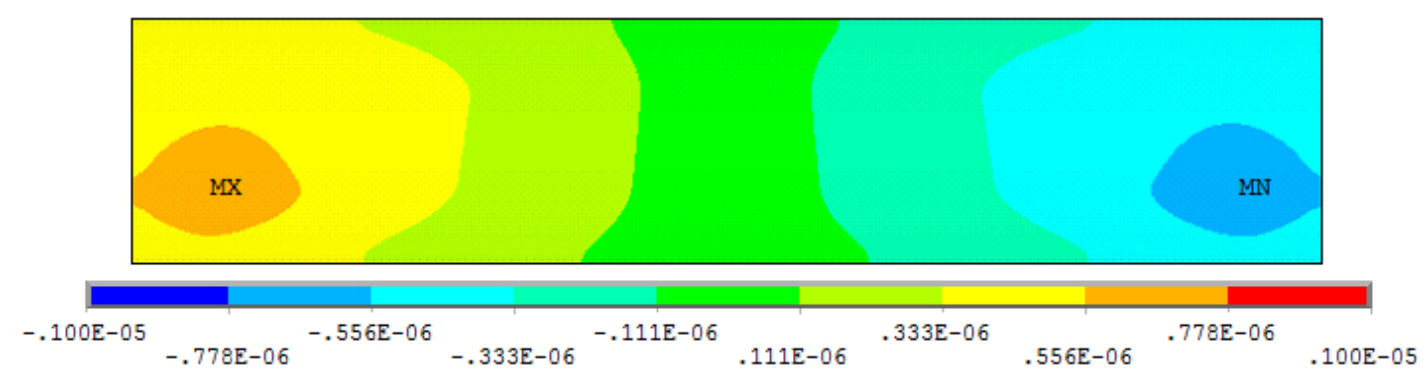

Figure 6: Strain on the rail web - inner surface (Straight track, Q100-Y0 kN, T $+0^{\circ} \mathrm{C}, \alpha=1 / 20, \mathrm{R}=75 \mathrm{MN} / \mathrm{m}$, New rail profile)

\subsection{Shear strain on the rail foot}

The Figure 7 and 8 show the shear strain on the rail foot under different loads conditions, while the wheelset is running on a curved track. In both figure, the shear strains, in specific areas on rail foot surfaces, have approximately the same value along the longitudinal axis (green areas). A proper combination of shear strain on the rail foot could give a constant value of the ratio between the force and strain as made in SMCT method [24]. The other test runs generate the same kind of results. 


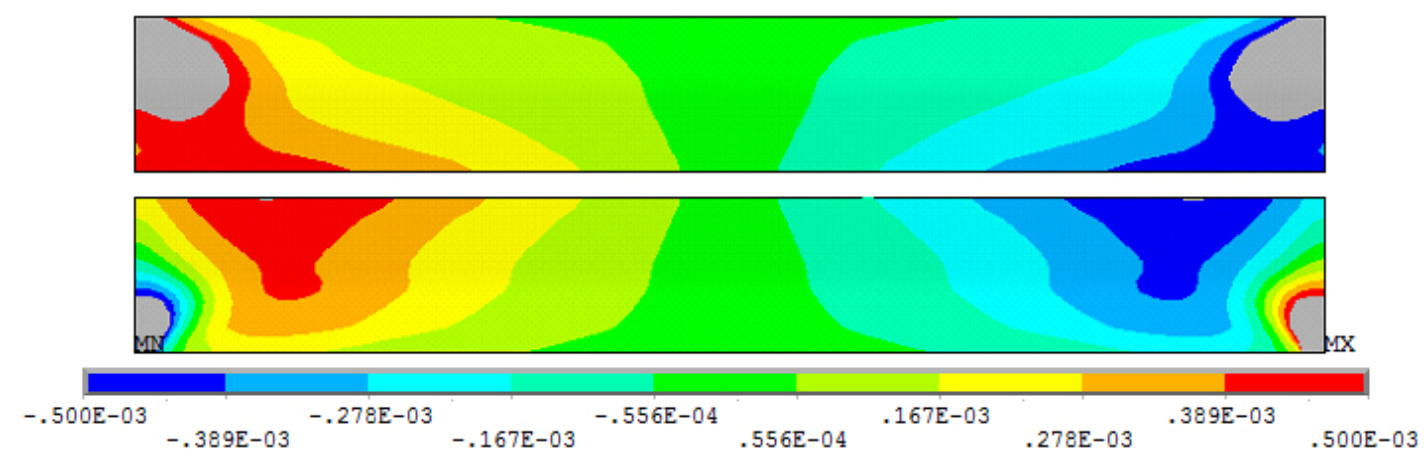

Figure 7: Strain on the rail foot (Curved track, Q100-Y50 kN, T $+0^{\circ} \mathrm{C}, \alpha=1 / 20$, $\mathrm{R}=75 \mathrm{MN} / \mathrm{m}$, New rail profile)

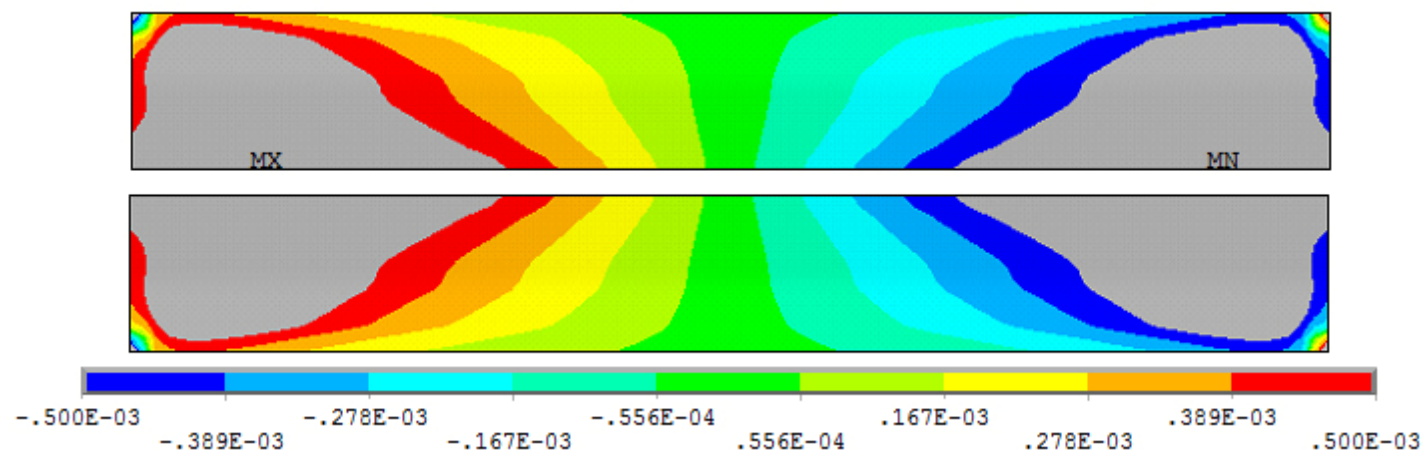

Figure 8: Strain on the rail foot (Curved track, Q100-Y100 kN, T $+0^{\circ} \mathrm{C}, \alpha=1 / 20$, $\mathrm{R}=75 \mathrm{MN} / \mathrm{m}$, New rail profile)

\subsection{Shear strain combination on the rail foot}

The shear strain combination used for the results analysis is based on SMCT method [24]. Table 9 and 10 list the sum of strains $(\Sigma \varepsilon)$ measured in four different point on rail foot on straight track and curved track. The Table 9 shows an approximately constant value of strain when the train is cornering, according to different values lateral force $(\mathrm{Y})$. Instead, the Table 10 shows that the value of strain is about zero when the train is in straight track. This results establish that the combination of the strains exclude the effects of the vertical force $(\mathrm{Q})$ on measure. In that way, it is possible to find a constant value of the ratio between the lateral force $(\mathrm{Y})$ and strain combination on rail foot useful for monitoring the wheel-rail contact forces.

The main effects of the considered parameters have been identified by analysing the boundary conditions and the theoretical results. For the wheelset running on straight track, the principal effects on a rail foot strain derived from the thermal gradient $(\Delta \mathrm{T})$ and from the geometry of the railhead profiles (new or worn). The first parameter modifies the surface stress distribution and the second changes the wheel-rail contact point. Instead, for the wheelset running on curved track (flange contact), the principal effects are produced by the loads combination (vertical and lateral force) and by the inclination of the rail $(\alpha)$. This is in according to the different values of forces components and to the changing of wheel-rail contact point. 


\begin{tabular}{|c|c|c|c|c|c|c|}
\hline $\mathbf{n}$ & Loads & $\Delta T$ & $\alpha$ & Rail profile & $\mathbf{R}$ & $\Sigma \varepsilon$ \\
\hline 1 & Q $100 \mathrm{kN}-\mathrm{Y} 50 \mathrm{kN}$ & $0{ }^{\circ} \mathrm{C}$ & $1 / 40$ & new & $1 \cdot 10^{30} \mathrm{~N} / \mathrm{m}$ & $186,5 \mu \varepsilon$ \\
\hline 2 & Q 100kN - Y 50kN & $0^{\circ} \mathrm{C}$ & $1 / 40$ & worn & $75 \cdot 10^{6} \mathrm{~N} / \mathrm{m}$ & $174,3 \mu \varepsilon$ \\
\hline 3 & Q 100kN - Y 50kN & $0^{\circ} \mathrm{C}$ & $1 / 20$ & new & $75 \cdot 10^{6} \mathrm{~N} / \mathrm{m}$ & $185,1 \mu \varepsilon$ \\
\hline 4 & Q 100kN - Y 50kN & $0^{\circ} \mathrm{C}$ & $1 / 20$ & worn & $1 \cdot 10^{30} \mathrm{~N} / \mathrm{m}$ & $189,9 \mu \varepsilon$ \\
\hline 5 & Q 100kN - Y 50kN & $50^{\circ} \mathrm{C}$ & $1 / 40$ & new & $75 \cdot 10^{6} \mathrm{~N} / \mathrm{m}$ & $185,0 \mu \varepsilon$ \\
\hline 6 & Q 100kN - Y 50kN & $50^{\circ} \mathrm{C}$ & $1 / 40$ & worn & $1 \cdot 10^{30} \mathrm{~N} / \mathrm{m}$ & $175,3 \mu \varepsilon$ \\
\hline 7 & $\mathrm{Q} 100 \mathrm{kN}-\mathrm{Y} 50 \mathrm{kN}$ & $50^{\circ} \mathrm{C}$ & $1 / 20$ & new & $1 \cdot 10^{30} \mathrm{~N} / \mathrm{m}$ & $186,4 \mu \varepsilon$ \\
\hline 8 & Q 100kN - Y 50kN & $50^{\circ} \mathrm{C}$ & $1 / 20$ & worn & $75 \cdot 10^{6} \mathrm{~N} / \mathrm{m}$ & $188,7 \mu \varepsilon$ \\
\hline 9 & $\mathrm{Q} 100 \mathrm{kN}-\mathrm{Y} 100 \mathrm{kN}$ & $0^{\circ} \mathrm{C}$ & $1 / 40$ & new & $75 \cdot 10^{6} \mathrm{~N} / \mathrm{m}$ & $370,1 \mu \varepsilon$ \\
\hline 10 & Q 100kN - Y 100kN & $0^{\circ} \mathrm{C}$ & $1 / 40$ & worn & $1 \cdot 10^{30} \mathrm{~N} / \mathrm{m}$ & $367,2 \mu \varepsilon$ \\
\hline 11 & Q $100 \mathrm{kN}-\mathrm{Y} 100 \mathrm{kN}$ & $0{ }^{\circ} \mathrm{C}$ & $1 / 20$ & new & $1 \cdot 10^{30} \mathrm{~N} / \mathrm{m}$ & $372,9 \mu \varepsilon$ \\
\hline 12 & Q $100 \mathrm{kN}-\mathrm{Y} 100 \mathrm{kN}$ & $0^{\circ} \mathrm{C}$ & $1 / 20$ & worn & $75 \cdot 10^{6} \mathrm{~N} / \mathrm{m}$ & $379,3 \mu \varepsilon$ \\
\hline 13 & $\mathrm{Q} 100 \mathrm{kN}-\mathrm{Y} 100 \mathrm{kN}$ & $50^{\circ} \mathrm{C}$ & $1 / 40$ & new & $1 \cdot 10^{30} \mathrm{~N} / \mathrm{m}$ & $372,9 \mu \varepsilon$ \\
\hline 14 & Q $100 \mathrm{kN}-\mathrm{Y} 100 \mathrm{kN}$ & $50^{\circ} \mathrm{C}$ & $1 / 40$ & worn & $75 \cdot 10^{6} \mathrm{~N} / \mathrm{m}$ & $364,7 \mu \varepsilon$ \\
\hline 15 & Q 100kN - Y 100kN & $50^{\circ} \mathrm{C}$ & $1 / 20$ & new & $75 \cdot 10^{6} \mathrm{~N} / \mathrm{m}$ & $370,1 \mu \varepsilon$ \\
\hline 16 & Q 100kN - Y 100kN & $50^{\circ} \mathrm{C}$ & $1 / 20$ & worn & $1 \cdot 10^{30} \mathrm{~N} / \mathrm{m}$ & $381,6 \mu \varepsilon$ \\
\hline
\end{tabular}

Table 9: Strain results on rail foot - Curved track

\begin{tabular}{|c|c|c|c|c|c|c|}
\hline $\mathbf{n}$ & Loads & $\Delta T$ & $\alpha$ & Rail profile & $\mathbf{R}$ & $\Sigma \varepsilon$ \\
\hline 1 & Q 50kN - Y 0kN & $0^{\circ} \mathrm{C}$ & $1 / 40$ & new & $1 \cdot 10^{30} \mathrm{~N} / \mathrm{m}$ & 0,005 \\
\hline 2 & Q 50kN - Y 0kN & $0^{\circ} \mathrm{C}$ & $1 / 40$ & worn & $75 \cdot 10^{6} \mathrm{~N} / \mathrm{m}$ & 0,000 \\
\hline 3 & Q 50kN - Y 0kN & $0^{\circ} \mathrm{C}$ & $1 / 20$ & new & $75 \cdot 10^{6} \mathrm{~N} / \mathrm{m}$ & 0,000 \\
\hline 4 & Q 50kN - Y 0kN & $0^{\circ} \mathrm{C}$ & $1 / 20$ & worn & $1 \cdot 10^{30} \mathrm{~N} / \mathrm{m}$ & $\mathbf{0 , 0 1 0}$ \\
\hline 5 & $\mathrm{Q} 50 \mathrm{kN}-\mathrm{Y} 0 \mathrm{kN}$ & $50^{\circ} \mathrm{C}$ & $1 / 40$ & new & $75 \cdot 10^{6} \mathrm{~N} / \mathrm{m}$ & $-0,030$ \\
\hline 6 & $\mathrm{Q} 50 \mathrm{kN}-\mathrm{Y} 0 \mathrm{kN}$ & $50^{\circ} \mathrm{C}$ & $1 / 40$ & worn & $1 \cdot 10^{30} \mathrm{~N} / \mathrm{m}$ & $-0,055$ \\
\hline 7 & $\mathrm{Q} 50 \mathrm{kN}-\mathrm{Y} 0 \mathrm{kN}$ & $50{ }^{\circ} \mathrm{C}$ & $1 / 20$ & new & $1 \cdot 10^{30} \mathrm{~N} / \mathrm{m}$ & $-0,025$ \\
\hline 8 & Q 50kN - Y 0kN & $50{ }^{\circ} \mathrm{C}$ & $1 / 20$ & worn & $75 \cdot 10^{6} \mathrm{~N} / \mathrm{m}$ & $-0,105$ \\
\hline 9 & Q $100 \mathrm{kN}-\mathrm{Y} 0 \mathrm{kN}$ & $0^{\circ} \mathrm{C}$ & $1 / 40$ & new & $75 \cdot 10^{6} \mathrm{~N} / \mathrm{m}$ & $\mathbf{0 , 0 0 0}$ \\
\hline 10 & Q $100 \mathrm{kN}-\mathrm{Y} 0 \mathrm{kN}$ & $0^{\circ} \mathrm{C}$ & $1 / 40$ & worn & $1 \cdot 10^{30} \mathrm{~N} / \mathrm{m}$ & $\mathbf{0 , 0 1 0}$ \\
\hline 11 & $\mathrm{Q} 100 \mathrm{kN}-\mathrm{Y} 0 \mathrm{kN}$ & $0^{\circ} \mathrm{C}$ & $1 / 20$ & new & $1 \cdot 10^{30} \mathrm{~N} / \mathrm{m}$ & 0,005 \\
\hline 12 & Q 100kN - Y 0kN & $0^{\circ} \mathrm{C}$ & $1 / 20$ & worn & $75 \cdot 10^{6} \mathrm{~N} / \mathrm{m}$ & $\mathbf{0 , 0 0 0}$ \\
\hline 13 & Q $100 \mathrm{kN}-\mathrm{Y} 0 \mathrm{kN}$ & $50^{\circ} \mathrm{C}$ & $1 / 40$ & new & $1 \cdot 10^{30} \mathrm{~N} / \mathrm{m}$ & $-0,025$ \\
\hline 14 & Q $100 \mathrm{kN}-\mathrm{Y} 0 \mathrm{kN}$ & $50^{\circ} \mathrm{C}$ & $1 / 40$ & worn & $75 \cdot 10^{6} \mathrm{~N} / \mathrm{m}$ & $-0,105$ \\
\hline 15 & Q 100kN - Y 0kN & $50^{\circ} \mathrm{C}$ & $1 / 20$ & new & $75 \cdot 10^{6} \mathrm{~N} / \mathrm{m}$ & $-0,030$ \\
\hline 16 & Q $100 \mathrm{kN}-\mathrm{Y} 0 \mathrm{kN}$ & $50^{\circ} \mathrm{C}$ & $1 / 20$ & worn & $1 \cdot 10^{30} \mathrm{~N} / \mathrm{m}$ & $-0,055$ \\
\hline
\end{tabular}

Table 10: Strain results on rail foot - Straight track 


\section{Conclusions}

The study confirms that the rail can be a useful, feasible, suitable, measuring device for the operating safety and maintenance of the track.

The theoretical approach has established that it is possible to obtain meaningful information to determinate the forces applied to the wheel on the rail.

The simulation results have been confirmed by the experimental tests made by the same research work group and by applications currently in use in the Italian Railways Infrastructure.

The study of the rail strain under different loads and conditions is a valid way for detecting further potential applications (i.e. stability of the rail and the supports).

\section{References}

[1] M. Bruner, C. Cosciotti, G.R. Corazza, "Lo svio - Cento e più anni di ricerche su un problema complesso - Gli inizi e la scuola francese", CIFI, Ingegneria Ferroviaria, dicembre 2009

[2] M. Bruner, C. Cosciotti, G.R. Corazza, "Lo svio - Cento e più anni di ricerche su un problema complesso - La scuola tedesca", CIFI, Ingegneria Ferroviaria, dicembre 2010

[3] M. Bruner, C. Cosciotti, G.R. Corazza, "Lo svio - Cento e più anni di ricerche sullo svio - I deragliatori”, CIFI, Ingegneria Ferroviaria, giugno 2012

[4] Code UIC 518 "Testing and approval of railway vehicle from the point of view of their dynamic behaviour - Safety - Track fatigue - Running behaviour", 2009

[5] EN14363 "Railway applications - Testing and Simulation for the acceptance of running characteristics of railway vehicles - Running Behaviour and stationary tests", 2012

[6] RTR Special: Wayside Train Monitoring System - An actual overview, Eurailpress, 2011

[7] K. Knothe, "GleisDynamik",Ernst\&Sohn 2001

[8] D. R. Ahlbeck, H.D. Harrison, "Technique for Measuring Wheel/Rail Forces with Trackside Instrumentation", ASME Winter Annual Meeting, 1977

[9] D. R. Ahlbeck, H.D. Harrison, "Techniques for Measurement of Wheel-Rail Forces", The Shock and Vibration Digest, 1980.

[10] H.D. Harrison, D.R. Ahlbeck "Development and evaluation of wayside wheel/rail load measurement techniques", Proceedings of the International Conference on Wheel/Rail Load and Displacement Measurement Techniques, 1981

[11] A. Moreau, "La verification del la securite contre le deraillement" RGCF, 1987

[12] L. Bocciolini, A. Bracciali, L. Di Benedetto, R. Mastandrea and F. Piccioli, "Wayside Measurement of Lateral and Vertical Wheel/Rail Forces for Rolling Stock Homologation", Second International Conference on Railway Technology, 2014. 
[13] M. Bruner, E. Carano and G. Malavasi "The Rail: A Sensor for Measurement of Forces Applied by the Wheel", Second International Conference on Railway Technology, 2014.

[14] F.M.D. Accattatis, M. Bruner, M. Catena, G.R. Corazza, E. Cosciotti, G. Malavsi, S. Rossi, M. Testa, "Measurement of the vertical loads transferred to the rail / Misura dei carichi verticali trasmessi alla rotaia", Ingegneria Ferroviaria, dicembre 2014

[15] Marketing brochure Schenck Multirail

[16] Marketing brochure HBM Argos

[17] S. Iwnicki "Handbook of Railway Vehicle Dynamics", Taylor \& Francis Group, LLC, 2006

[18] Code UIC 519 "Methode de determination de la conicite equivalente", 2004

[19] EN15302 "Railway applications - Method for determining the equivalent conicity", 2011

[20] M. Albano, "Problematiche della simulazione e del comportamento reale dei veicoli ferroviari", Tesi di Dottorato in Ingegneria Ferroviaria XV Ciclo, Università degli Studi di Roma "La Sapienza", 2006

[21] C. Esveld, "Modern Railway Track", TU Delft, MRT Productions, 2001

[22] Universal Mechanism, User Guide (http://www.universalmechanism.com)

[23] Kalker, "Wheel-rail rolling contact theory", Elsevier, Wear n.144, 1991

[24] M. Bruner, F. Campagna, D. Cortis, Gi. Malavasi, S. Rossi, "Tecniche di misura sperimentali per la determinazione delle forze laterali di contatto ruotarotaia", IV Convegno Nazionale "Sicurezza ed Esercizio Ferroviario: Soluzioni e Strategie per lo Sviluppo del Trasporto Ferroviario", Università degli Studi di Roma "La Sapienza", 2015 